\title{
Articles
}

Reinhard Zimmermann

Codification

\section{The Civilian Experience Reconsidered on the Eve of a Common European Sales Law}

\begin{abstract}
This essay, after determining the characteristics constituting a codification, sets out the historical conditions for the creation of national codifications in the late $18^{\text {th }}$ and early $19^{\text {th }}$ centuries. It then deals with a number of myths and misconceptions associated with codifications. The Proposal for a Regulation on a Common European Sales Law has now firmly placed the issue of codification on the European legal agenda. The essay therefore attempts to assess its chances of success against the background of the historical experiences; thus, it considers the arguments that have, in the past, been advanced in favour of codifications of private law and also looks at other factors that have contributed to their success. All in all, the auspices for a European Code of Contract Law, let alone a Civil Code, are far from ideal.
\end{abstract}

Résumé: Après avoir posé les éléments caractéristiques d'une codification, nous exposerons les conditions historiques de la création des codifications nationales à la fin du 18ème et au début du 19ème siècle. À l'époque, un certain nombre de mythes et d'opinions erronées étaient associés aux codifications. La proposition de règlement relatif à un droit commun européen de la vente a à présent fermement inscrit la codification à l'agenda législatif européen. Nous essaierons alors d'évaluer ses chances de succès par rapport aux expériences historiques; nous examinerons alors les arguments qui ont été avancés, dans le passé, en faveur des codifications de droit privé, et analyserons dans un second temps les autres facteurs qui ont contribué à leur succès. Somme toute, les conditions de succès pour un Code européen des contrats, et plus encore pour un Code civil, sont loin d'être idéales.

Zusammenfassung: Der vorliegende Beitrag befasst sich zunächst mit den Charakteristika einer Kodifikation sowie mit den historischen Bedingungen für das Entstehen der nationalen Kodifikationen im späten 18. und frühen 19. Jahrhundert. Er wendet sich dann einer Reihe von Legenden und Fehlvorstellungen zu, die sich um diese Errungenschaft der europäischen Rechtskultur herumranken. Der Vorschlag für eine Verordnung über ein Gemeinsames Europäisches Kauf- 
recht hat nunmehr das Thema „Kodifikation“ auf die Agenda moderner europäischer Rechtsvereinheitlichung gesetzt. Der Beitrag versucht daher, die Erfolgschancen dieses Vorschlags vor dem Hintergrund der historischen Erfahrung zu beurteilen. Er befasst sich mit den Argumenten, die historisch zugunsten einer Kodifikation des Privatrechts wurden, und mit anderen Faktoren, die zu ihrem Erfolg beigetragen haben. Alles in allem, so das Ergebnis, sind die Vorzeichen für eine Kodifikation des Vertragsrechts, oder gar des Privatrechts insgesamt, nicht günstig.

Reinhard Zimmermann: Max-Planck-Institut für ausländisches und internationales Privatrecht, Mittelweg 187, 20148 Hamburg, Germany, E-Mail: r.zimmermann@mpipriv.de

\section{Table of Content}

1 The Idea of Codification - 369

2 The Concept of Codification - 371

3 Historical Conditions - $\mathbf{3 7 4}$

(i) The rise of the modern state $-\mathbf{3 7 4}$

(ii) Symbol of political unity - $\mathbf{3 7 4}$

(iii) Cultural homogeneity - $\mathbf{3 7 4}$

(iv) The authority of Roman law undermined - 374

(v) Legal pluralism - 375

(vi) Enlightened governance - $\mathbf{3 7 5}$

(vii) The 'law of reason' - $\mathbf{3 7 5}$

(viii) Rule of law - 376

4 Historical School and BGB - 376

5 Myths and Misconceptions - $\mathbf{3 7 8}$

(i) Learned lawyers remain indispensable - $\mathbf{3 7 8}$

(ii) Who drafts a codification? - $\mathbf{3 7 8}$

(iii) Codification as restatement $\mathbf{3 7 8}$

(iv) A 'prison cell' for legal scholarship? - 379

(v) Codification and legal culture -379

(vi) Vertical and horizontal isolation - $\mathbf{3 8 0}$

(vii) 'Historical legal science' today? - $\mathbf{3 8 1}$

(viii) The ideal of comprehensiveness - two rationalities of private law? - 382

6 From the National to the European Level - $\mathbf{3 8 4}$

7 The Codification Controversy on a European Level - $\mathbf{3 8 9}$

(i) Tidying up the European legal landscape? - 389 
(ii) Constitutional function? - $\mathbf{3 8 9}$

(iii) Part of a process of state formation? - $\mathbf{3 9 0}$

(iv) Facilitating trade? - 391

(v) Codification and legal scholarship _ 392

(vi) Codification and legal scholarship (continued) - 393

(vii) Codification and the courts -394

(viii) Structural and procedural deficits -395

8 Opening up the Discourse or Limiting it? _ 396

1

Codification, in the words of Franz Wieacker, is 'a unique creation, hard-won and hard to be defended, of Central and Western Continental legal culture'. ${ }^{1}$ For Max Weber, it constituted a culmination, in the field of law, of a specifically European quest for rationality. ${ }^{2}$ At the same time, according to Pio Caroni, codification was a fundamental turning point, and thus ushered in a new era, in the history of European law. ${ }^{3}$ The age of codification has in fact characteristically shaped our modern legal landscape and still, to a large extent, determines our legal mind. ${ }^{4} \mathrm{~A}$ codex, originally, was a set of wooden tablets covered with material used for

1 F. Wieacker, 'Aufstieg, Blüte und Krisis der Kodifikationsidee', in Festschrift für Gustav Boehmer (Bonn: Roehrscheid, 1954) 34 (translation from the German original here and throughout the article by R.Z., unless otherwise indicated).

2 M. Weber, 'Die Entwicklungsbedingungen des Rechts', in W. Gephart and S. Hermes (eds), Wirtschaft und Gesellschaft, Teilband 3: Recht (Tübingen: Mohr Siebeck, 2010) 569 et seq. 3 P. Caroni, Gesetz und Gesetzbuch: Beiträge zu einer Kodifikationsgeschichte (Munich: Helbing \& Lichtenhahn, 2003) viii.

4 For earlier reflections on the same topic, see R. Zimmermann, 'Codification: History and Present Significance of an Idea' (1995) 3 European Review of Private Law 95 et seq. For recent overviews, see P. Caroni, 'Kodifikation', in A. Erler (ed), Handwörterbuch zur deutschen Rechtsgeschichte, volume II (Berlin: Schmidt, 1978) 907 et seq; P. Caroni, 'Kodifikation', in F. Jaeger (ed), Enzyklopädie der Neuzeit (Stuttgart: Metzler, 2007) 855 et seq (referring to a 'revolutionary transformation'); B. Dölemeyer, 'Kodifizierung/Kodifikation', in Der Neue Pauly: Enzyklopädie der Antike, volume 14 (Rezeptions- und Wissenschaftsgeschichte) (Stuttgart: Metzler, 2000) 1003 et seq; J.P. Schmidt, 'Codification', in J. Basedow, K.J. Hopt and R. Zimmermann (eds), The Max Planck Encyclopedia of European Private Law (MaxEuP) (Oxford: Oxford University Press, 2012) 221 et seq (based upon a more extensive discussion in J.P. Schmidt, Zivilrechtskodifikation in Brasilien [Tübingen: Mohr Siebeck, 2009] 133 et seq); N. Jansen and L. Rademacher, 'European Civil Code', in J. Smits (ed), Elgar Encyclopedia of Comparative Law ( $2^{\text {nd }}$ ed, Cheltenham: Elgar, 2012). 
writing and bound together in the form of a booklet. ${ }^{5}$ Codices, in the sense of law books or collections of laws, have been produced since time immemorial: the Code of Hammurabi, the XII Tables, the Codex Theodosianus, ${ }^{6}$ the so-called leges barbarorum, Decretum Gratiani, Sachsenspiegel, ${ }^{7}$ Siete Partidas, and many more. ${ }^{8}$ But the modern phenomenon of codification, referred to by Weber, Wieacker and Caroni, is a product of the age of Enlightenment, ${ }^{9}$ and its principal manifestations were the Prussian code (Preußisches Allgemeines Landrecht) of 1794, the Austrian General Civil Code (Allgemeines Bürgerliches Gesetzbuch = ABGB) of 1811, and the French Code civil of 1804. The Code civil provided the model for the codifications of Dutch (1838), Italian (1865), Portuguese (1867) and Spanish private law (188889). A second 'wave' of codifications caught Germany (1900), Switzerland (1881/ 1911/1937: Law of Obligations [Obligationenrecht = OR]; 1907/1912: Civil Code [Zivilgesetzbuch = ZGB]), and Greece (1946). ${ }^{10}$ Italy (1942), Portugal (1967) and the Netherlands (from 1970 onwards) have recodified their private laws; ${ }^{11}$ the Austrian (1914-1916) and German (particularly in 2002) codes have been the subject of major reforms; and similar reform processes are currently under way in France

5 A. Berger, Encyclopedic Dictionary of Roman Law (Philadelphia: The American Philosophical Society, 1953) 391; R. Cabrillac, Les codifications (Paris: Presses Universitaires de France, 2002) 56 et seq (not only on the etymology but also on the history of the term codex).

$6 \mathrm{See}$, in the present context, I. Kroppenberg, 'Der gescheiterte Codex: Überlegungen zur Kodifikationsgeschichte des Codex Theodosianus' (2007) 10 Rechtsgeschichte 112.

Kroppenberg, however, uses the concept of codification to cover also documents such as the Codex Theodosianus, or indeed the XII Tables: 'Mythos Kodifikation - Ein rechtshistorischer Streifzug' (2008) Juristenzeitung 910 (n 109). P. Caroni, ‘(De)Kodifikation: wenn historische Begriffe ins Schleudern geraten', in K.V. Maly and P. Caroni (eds), Kodifikation und Dekodifikation des Privatrechts in der heutigen Rechtsentwicklung (Prague: Karolinum, 1998) 32 et seq criticizes this as an ahistorical projection of modern concepts into the past ('... if the concepts start floundering'). Others use the concept of codification in a wide, and untechnical, sense; see Cabrillac, $n 5$ above, 63 who proposes to define 'le noyau dur du concept de code comme un ensemble de règles juridiques mises en forme' and the concept of codification as 'cette operation de mise en forme de règles juridiques en un ensemble' (this is based on J. Vanderlinden, Le concept de code en Europe occidentale du XIIle au XIXe siècle: Essay de définition [Bruxelles: Editions de l'Institut de Sociologie, Université libre de Bruxelles, 1967]). 7 On the two latter see, in the present context, N. Jansen, The Making of Legal Authority: Nonlegislative Codifications in Historical and Comparative Perspective (Oxford: Oxford University Press, 2010) 21 et seq.

8 For an overview, see Cabrillac, $\mathrm{n} 5$ above, 10 et seq.

9 Cabrillac, $\mathrm{n} 5$ above, 33, refers to the '[s]iècle d'or de la codification'.

10 On the spread of codifications throughout large parts of the world see Cabrillac, n 5 above, 40 et seq; Schmidt, in MaxEuP, $\mathrm{n} 4$ above, 222 et seq.

11 On the problems relating to recodification, see Cabrillac, $\mathrm{n} 5$ above, 107 et seq. 
and Spain. ${ }^{12}$ (The Prussian code, of course, was replaced by the German BGB.) From Central, Western, and Southern Europe the codification movement spread to other parts of the world, most notably to Eastern and South-Eastern Europe, East Asia, Latin America, the francophone countries of Africa, and the mixed legal systems of Israel, Québec and Louisiana.

All of these modern codes differ in a number of respects. ${ }^{13}$ Predominantly they deal with general private law but sometimes (eg in Italy) they also include commercial law ${ }^{14}$ (or even public law: the Prussian code); usually they have been drafted and redrafted by (a sequence of) committees but sometimes (eg in Switzerland) they are the product of individual masterminds; $;^{15}$ mostly they are enacted, in their entirety, at one specific moment, but sometimes (eg in the Netherlands) their various parts are drafted and enacted in stages; normally, they apply directly, but sometimes (eg in Spain) ${ }^{16}$ they are applicable only in subsidio, at least for certain parts of the relevant country and for certain areas of the law.

\section{2}

What, then, are the common characteristics constituting a codification in the modern, or technical, sense of the word? In the first place, codification is an act of legislation, ie its validity is based on the intervention of the state. However, in the words of Jeremy Bentham, the person who coined the term, codification is '[q]uite different [from] ordinary legislation' in view of the fact that here 'of the entire field of law ... some very large portion ... is to receive an entire new

12 J. Cartwright, S. Vogenauer, S. Whittaker (eds), Reforming the French Law of Obligations (Oxford: Hart, 2009); C.J. Delgado and M.J.P. García, 'The General Codification Commission and the Modernisation of the Spanish Law of Obligations' (2011) 19 Zeitschrift für Europäisches Privatrecht 600 et seq.

13 Cf also J.Fr. Behrend, 'Die neueren Privatrechts-Codificationen', in F. von Holtzendorff (ed), Encyclopädie der Rechtswissenschaft, Part I (Leipzig: Duncker \& Humblot, 1870) 229 et seq (Codifications 'can be very different, as far as their validity, object, content and size are concerned').

14 See Schmidt, in MaxEuP, n 4 above, 210 et seq.

15 See Cabrillac, n 5 above, 214 et seq; B. Mertens, Gesetzgebungskunst im Zeitalter der Kodifikationen (Tübingen: Mohr Siebeck, 2004) 88 et seq; cf also the remarks by Wieacker, n 30 below, 474 .

16 See C. Eckl, 'Código Civil', in MaxEuP, n 4 above, 225 et seq; for Prussia, see Behrend, n 13 above, 236 . 
covering all at once'. ${ }^{17}$ A codification, therefore, does not concern itself with individual issues that need to be regulated but covers an area of the law: general private law, the law of obligations (including or excluding commercial obligations), contract law, family law, etc. In addition, a codification aims to be comprehensive (or 'complete'). This ideal of completeness has three dimensions: ${ }^{18} \mathrm{a}$ codification should not contain gaps; it should replace the general law prevailing before its enactment ${ }^{19}$ and thus constitute the new 'epicentre'20 of the system of sources of law (for this reason, the Codex Maximilianeus Bavaricus Civilis of 1756 was not a modern codification); ${ }^{21}$ and it should gather all the relevant legal rules in one place, ie not coexist with specific statutes within one and the same area of the law. No codification, however, has ever fully complied with this ideal. ${ }^{22}$ Moreover, a codification is not just the recording of the rules pertaining to a certain field of law. It is based on the belief that the legal rules can be reduced to a rational system..$^{23}$ A codification, therefore, aims at presenting its subject matter as a

17 J. Bentham, 'Papers relative to Codification and Public Instruction', in J. Bowring (ed), The Works of Jeremy Bentham, volume IV (Edinburgh: Tait, 1843) 518.

18 Mertens, n 15 above, 325 et seq. Generally on 'l'effet de complétude' of codifications, cf also Cabrillac, $\mathrm{n} 5$ above, 105 et seq.

19 In the words of Bentham, n 17 above, 519, it has to 'reduce the old matter, in its whole extent, to a non-entity'; Cabrillac, $n 5$ above, 90: 'Dès son entrée en vigeur, le code efface d'un trait de plume le monde juridique qui le précède'.

20 Caroni, $\mathrm{n} 3$ above, 38.

21 Justinian's Corpus Juris, though no longer taken to be the 'infallible legal gospel', was still to be attributed subsidiary force: W.X.A.F. von Kreittmayr, Anmerkungen über den Codicem Maximilianeum Bavaricum Civilem, Part I (Munich: Vötter, 1759) chapter 2, § 9, no 20.

22 That there may be gaps was acknowledged even by the draftsmen of the Prussian code. Since the middle of the $19^{\text {th }}$ century it was generally recognized that any codification was bound to contain gaps; indeed, the draftsmen of the BGB deliberately left many questions open for determination by courts and legal scholarship. However, in modern terminology, we are dealing here with 'internal' gaps that can be filled on the basis of the code and its underlying principles. - All modern codifications intended to end the (subsidiary) application of Roman law. But the Austrian code allows the judge to refer to the principles of Natural law (§ 7 ABGB), while the Swiss Civil Code, if no relevant provision can be found for a legal problem, refers the judge to customary law as well as 'to the rule which he would, were he the legislator, adopt' (art 1[2] ZGB). - The third dimension inherent in the notion of 'completeness' was largely taken account of only by the Prussian code. In the Introductory Act to the BGB, for example, close to 100 articles dealt with subject matters to be left to special legislation by the individual states; cf also infra text to $\mathrm{n} 82$ below. For details, see Mertens, $\mathrm{n} 15$ above, 326 et seq, 336 et seq, 344 et seq; Schmidt (2009), $\mathrm{n} 4$ above, 134 et seq.

23 Mertens, n 15 above, 421 et seq; S. Vogenauer, Die Auslegung von Gesetzen in England und auf dem Kontinent (Tübingen: Mohr Siebeck, 2001) 649; Jansen and Rademacher, n 4 above, sub 4. 
logically consistent entity of legal rules and institutions. It thus promotes the internal coherence of the law and makes it more easily comprehensible. And it supplies both the conceptual tools and the intellectual matrix for the further development of the law. The third characteristic of a codification, therefore, is its systematic nature; hence Justinian's Code and Digest, or the Decretum Gratiani, do not constitute codifications in the same, technical sense as the Code civil or the German Civil Code (Bürgerliches Gesetzbuch = BGB).

But what about Justinian's Institutes? They were designed to provide a comprehensive and systematic account of Roman private law, and they were invested with the force of law. ${ }^{24}$ None the less, no one today would regard them as a codification. Thus, probably, a fourth element has to be added to the definition of a codification, and this has to do with the form of the texts contained in a codification..$^{25}$ The Institutes were a legal textbook; and as such they contained 'a mixture of statement of present law, historical description and discussion of legal theory'. ${ }^{26}$ In particular, also, they presented legal arguments which their reader might regard as more or less convincing. Modern codifications, however, even if their style of legal drafting displays considerable differences, tend to make clear that they are not intended to be a contribution to an academic discourse but that they are to be observed and applied in practice. They are thus, to a greater or lesser extent, ${ }^{27}$ based on the precept of lex iubeat non disputet. ${ }^{28}$ A related point is made when it is stated that a codification is 'a new text, specifically drafted for

24 O. Behrends, 'Die Institutionen Justinians als Lehrbuch, Gesetz und Ausdruck klassischen Rechtsdenkens', in O. Behrends, R. Knütel, B. Kupisch and H.H. Seiler (eds and transl) Corpus Juris Civilis: Text und Übersetzung, volume I ( $2^{\text {nd }}$ ed, Heidelberg: Müller, 1997) 279 et seq. 25 Generally on 'text-related factors' concerning 'the making of legal authority' (though of 'non-legislative codifications' rather than of legislation), see Jansen, $\mathrm{n} 7$ above, 99 et seq. 26 American Law Institute, 'Report of the Committee on the Establishment of a Permanent Organization for the Improvement of the Law Proposing the Establishment of an American Law Institute' (1923) 1 Proceedings of the American Law Institute 20.

27 The Austrian and Prussian codes mark a transitional stage within a development from an instructive to a prescriptive style of legal drafting. The early modern legislation prior to the Prussian code (including the Codex Maximilianeus Bavaricus Civilis of 1756) has been described as constituting 'textbooks invested with the force of law'. For details, see Mertens, n 15 above, 312 et seq.

28 This is one reason why the 'European Civil Code' envisaged by H. Collins is not a codification in the technical sense of the word: it is conceived as a 'framework of normative standards ... rather than a complex body of detailed rules', ie a set of 'common legal principles'. The other reason is that this 'code' is supposed to operate 'as directive'; it 'would not comprise the sole source of private law. On the contrary, national private law systems must continue': H. Collins, The European Civil Code: The Way Forward (Cambridge: Cambridge University Press, 2008) x, 2, 189. 
the occasion'29 ${ }^{29}$ ather than the official collection of laws or cases, or the compilation of fragments, from earlier legal literature.

\section{3}

Codification was a historical phenomenon originating in the $18^{\text {th }}$ century, and implemented from the end of that century onwards..$^{30}$ What were the historical conditions responsible for it? (i) The idea of codification was closely associated with the rise of the modern sovereign state, exercising exclusive control over the legislative process. ${ }^{31}$ (ii) It was thus a potent symbol of the one and undivided nation and of political unity (this is particularly apparent in the cases of Italy and Germany). ${ }^{32}$ In the words of the main draftsman of the Code civil, Jean-Étienne Marie Portalis, it was to ensure that there were no longer Bretons, Alsatians or Provençals, but only Frenchmen. ${ }^{33}$ (iii) Codifications also contributed towards cultural homogeneity within the new, sovereign states. ${ }^{34}$ This is one of the reasons why they were drafted in the vernacular. (iv) They provided a response to a pervasive sense of crisis, as far as the administration of the law was concerned. For, on the one hand, Roman law had constituted the foundation of the ius commune prevailing in medieval and early modern Europe..$^{35}$ But its authority had been undermined by influential authors such as Franciscus Hotomannus, Hermann Conring and Christian Thomasius. ${ }^{36}$ It no longer appeared to be selfevidently right to apply a law that was riddled with inconsistencies, that had

29 R.C. van Caenegem, Judges, Legislators and Professors (Cambridge: Cambridge University Press, 1987) 42.

30 The classical general account is F. Wieacker, A History of Private Law in Europe (Oxford: Clarendon Press, 1995; transl Tony Weir from the $2^{\text {nd }}$ German edition, 1967) 199 et seq.

31 See D. Willoweit, Deutsche Verfassungsgeschichte (Munich: C H Beck, 2009) 152 et seq. The connection with the state (first the modern territorial, then the 'nation' state) is also apparent from the title of S. Meder, 'Die Krise des Nationalstaates und ihre Folgen für das Kodifikationsprinzip' (2006) Juristenzeitung 477 et seq.

32 Cf also Cabrillac, $n 5$ above, 154 et seq. For the rise of the sense of national identity in $19^{\text {th }}$ century Europe, in cultural-historical perspective, see J. Leerssen, National Thought in Europe (Amsterdam: Amsterdam University Press, 2006).

33 See J.G. Locré, La législation civile, commerciale et criminelle de la France, ou commentaire et complément des codes Français, volume I (Paris: Treuttel \& Würz, 1827) 348. - Generally, see Mertens, $\mathrm{n} 15$ above, 30 et seq.

34 See, eg, Leerssen, $\mathrm{n} 32$ above, 137 et seq.

35 N. Jansen, 'lus Commune', in MaxEuP, n 4 above, 1006 et seq; Jansen, $\mathrm{n} 7$ above, 13 et seq.

36 Cf further R. Zimmermann, 'Christian Thomasius, the Reception of Roman Law and the History of the lex Aquilia', in C. Thomasius, Larva Legis Aquiliae: The mask of the lex Aquilia 
given rise to intricate doctrinal disputes, that was wedded to outdated and impractical subtleties, and that had been enacted by despotic rulers of another age and country. (v) On the other hand, Roman law had never been on its own. The dualism of Empire and Church had been reflected in the dualism of Roman law and Canon law. Moreover, there was an enormous variety of territorial, regional and local laws, of statutes, customs and privileges that, in theory, enjoyed precedence before the courts. There were, of course, certain meta-rules that were supposed to govern the application of the law; ${ }^{37}$ but what actually happened in the courtrooms across Europe was subject to considerable change, and it could vary from place to place and from subject area to subject area. Thus, potential litigants and lawyers were faced with 'a legal pluralism hardly imaginable today', entailing very considerable legal uncertainty. ${ }^{38}$ Even a preliminary issue such as whether a secular or ecclesiastical court was competent to decide a dispute could give rise to lengthy and complex controversies. ${ }^{39}$ (vi) The rulers of the age of Enlightenment were bound to be repelled by this state of affairs and regarded it as their duty to promote the public welfare by not only centralizing but also rationalizing and clarifying the law. The legal rules according to which justice was to be dispensed had to be made known so that everybody could be expected to adjust his behaviour accordingly..$^{40}$ This was the other reason why the codifications were no longer drafted in the traditional language of the learned lawyers, but in the vernacular. ${ }^{41}$ (vii) At the same time, the mud holes of the glossators, ${ }^{42}$ and their successors, had to be drained by laying down the law in an easily comprehensible form rather than in an overabundant and arcane legal literature. To this end, the monarchs and their officials could avail themselves of

torn off the action for damage done (ed and transl Margaret Hewett) (Oxford: Hart, 2000) 56 et seq.

37 Lex posterior derogat legi anteriori; lex specialis derogat legi generali; statuta sunt stricte interpretanda; ubi cessat statutum habet locum ius civile; qui habet regulam juris communi pro se, habet fundatam intentionem; see J. Schröder, Recht als Wissenschaft $\left(2^{\text {nd }}\right.$ ed, Munich:

C H Beck, 2012) 19 et seq, 113 et seq.

38 See P. Oestmann, Rechtsvielfalt vor Gericht (Frankfurt: Klostermann, 2002) 681.

39 For details, see now P. Oestmann, Geistliche und weltliche Gerichte im Alten Reich:

Zuständigkeitsstreitigkeiten und Instanzenzüge (Köln: Böhlau, 2012).

40 This view presupposes that codifications are addressed (also) to the general population. During the age of Enlightenment, promotion of the general knowledge of the law was conceived as one of the state's tasks: for details, see Mertens, n 15 above, 251 et seq; Cabrillac, n 5 above, 218 et seq.

41 For details, see Mertens, $\mathrm{n} 15$ above, 386 et seq; cf also Cabrillac, n 5 above, 226 et seq.

42 The expression, law derived 'ex lacunis glossatorum' (as opposed to 'ex genuinis fontibus'), was used by Christian Thomasius; see Zimmermann, n 36 above, 58. 
the systems and theories of the new, secularized brand of Natural law that had emerged in the course of the $17^{\text {th }}$ century. Roman law was no longer ratio scripta; it was acceptable only in so far as it was in conformity with the principles of natural reason. A variety of writers (Hugo Grotius, Samuel Pufendorf, Christian Wolff, Jean Domat) had set out to demonstrate how the solutions to individual cases could be derived from general propositions and how all the rules regulating human behaviour could be fitted into a system that was both internally consistent and consonant with human reason and the nature of man. This culminated in a jurisprudence constructed more geometrico; and it is obvious that this type of jurisprudence appealed to authorities eager to rationalize the administration of justice. (viii) Inherent in the idea of codification, however, was also an emancipatory element: for by making the legal rules both public and certain, it promoted the rule of law. Thus, it suited not only the interests of those who ruled but also those of the reformers; and it appeared to be in line with contemporary Enlightenment philosophers such as John Locke who saw the origin of state and law in a kind of contract concluded in order to ensure liberty, equality and the protection of property.

\section{4}

It was in this spirit that the Prussian, Austrian and French codes were drafted, ${ }^{43}$ and it is interesting to see that the triumphal advance of the codification movement was only temporarily slowed down, but not stopped, when the intellectual climate changed: when the Romantic reaction led lawyers to lose faith in discovering a law of reason and to gain confidence, once again, in the traditions of the ius commune which could be moulded into a system of 'contemporary' Roman law. The great codification dispute in $1814^{44}$ was to inspire the creation of the Historical School ${ }^{45}$ and resulted in Germany not acquiring a code modelled

43 Wieacker, n 30 above, 257 et seq.

44 The relevant texts by A.F.J. Thibaut ('Über die Notwendigkeit eines allgemeinen bürgerlichen Rechts für Deutschland' [1814]) and F.C. von Savigny ('Vom Beruf unserer Zeit für Gesetzgebung und Rechtswissenschaft' [1814]) are easily accessible in H. Hattenhauer (ed), Thibaut und Savigny: Ihre programmatischen Schriften ( $2^{\text {nd }}$ ed, Munich: Vahlen, 2002). For a recent discussion (the codification dispute as a 'mythical narrative'), see Kroppenberg (2008), n 6 above, 905 et seq.

45 On which, see Wieacker, n 30 above, 279 et seq; T. Rüfner, 'Historical School', in MaxEuP, $\mathrm{n} 4$ above, 830 et seq. On Roman law in $19^{\text {th }}$ century Germany, see R. Zimmermann, Roman Law, Contemporary Law, European Law: The Civilian Tradition Today (Oxford: Oxford University Press, 2001) 6 et seq. 
on the Code civil. ${ }^{46}$ None the less it was widely accepted, from about the middle of the $19^{\text {th }}$ century onwards, that a German civil code was about to come. Among the German lawyers, as Bernhard Windscheid, one of Savigny's most faithful disciples, wrote in 1878, 'there are probably relatively few who have not, with all the strength of soul available to them, yearned for the great work of a German code of private law'. ${ }^{47}$ Obviously, these sentiments were intimately related to the fulfilment of the national aspirations of the German peoples, culminating in the creation of the (second) Reich in 1871. The BGB of 1900, of course, was different, in many respects, from the codifications of the era of the law of reason: it incorporated 19th century pandectist learning, it was based on a systematic design that differed from its predecessors, ${ }^{48}$ and it was drafted in more abstract conceptual language. ${ }^{49}$ But, then, the earlier codifications also displayed considerable differences from each other; one need only compare the 'sprung diction of the Code civil, instinct with the ideal of equality and freedom among citizens ${ }^{50}$ with the caring and fatherly tone of the Austrian code (or, indeed, with the prolix casuistry of the Prussian code). ${ }^{51}$ In spite of the fact that it was created under different auspices, the BGB was a true codification in the sense sketched above.

46 If Friedrich Carl von Savigny argued, famously and influentially, that the time was not yet 'ripe' for enacting a codification for the German states, he was inspired by the ideal of 'completeness' of a codification: it would have to contain a system of principles and rules which would make recourse to legal sources outside of the code unnecessary; such system, however, first had to be developed by contemporary legal scholarship; and his own most important work of a doctrinal nature, 'System des heutigen Römischen Rechts' (8 volumes, 1840 et seq), attempted to do just that. Cf also Mertens, $n 15$ above, 342.

47 B. Windscheid, 'Die geschichtliche Schule in der Rechtswissenschaft' (1878), in P. Oertmann (ed), Gesammelte Reden und Abhandlungen (Leipzig: Duncker \& Humblot, 1904) 70.

48 See J.P. Schmidt, 'Pandektensystem', in MaxEuP, n 4 above, 1238 et seq; R. Zimmermann, The Law of Obligations: Roman Foundations of the Civilian Tradition (Oxford: Clarendon Press, 1996) 29 et seq.

49 On the BGB, its origin and its characteristics, see H. Haferkamp, 'Bürgerliches Gesetzbuch', in MaxEuP, $\mathrm{n} 4$ above, 120 et seq; R. Zimmermann, 'The German Civil Code and the Development of Private Law in Germany', in R. Zimmermann, The New German Law of Obligations: Historical and Comparative Perspectives (Oxford: Oxford University Press, 2005) 5 et seq.

50 K. Zweigert and H. Kötz, An Introduction to Comparative Law (3 $3^{\text {rd }}$ ed, Oxford: Clarendon Press, 1998, transl Tony Weir) 144; cf also Weber, n 2 above, 592.

51 Zweigert and Kötz, n 50 above, 162, 137 et seq. 


\section{5}

If the story of the codification movement is a success story (as indeed it is) this is in spite of the fact that some of the high hopes and expectations associated with codifications have never been fulfilled; and that a number of myths and misconceptions have occasionally surrounded their nature and effects..$^{52}$ (i) According to Montesquieu, '[l]es lois ne doivent point être subtiles: elles sont faites pour des gens de médiocre entendement; elles ne sont point un art de logique, mais la raison simple d'un père de famille'.53 Other enlightenment lawyers, some of them involved in the drafting of the Prussian and Austrian codes, harboured similar ideals. ${ }^{54}$ And while the codifications significantly reduced the complexity of legal sources, and thus also of the application of the law, they never rendered the learned lawyer redundant. Even a comprehensive and systematic body of written law cannot be fully understood and safely applied by a layman. This is unavoidable, given the sophistication of our legal culture and the complexity of the modern world. (ii) The codifications are acts of legislation and thus derive their authority from the state. Unlike most individual statutes on taxation, trade or agriculture, however, they have not been written by members of Parliament, nor even usually by government officials, but by distinguished experts from legal practice or legal scholarship: Portalis and his three colleagues on the editorial committee, Karl Anton Freiherr von Martini and Franz Anton Felix von Zeiller, Gottlieb Planck and Bernhard Windscheid, Walther Munzinger and Eugen Huber, Eduard Maurits Meijers. This still holds true today, as can be seen in the preparation of the reform of the French and German law of obligations (or of Austrian liability law). ${ }^{55}$ And just as the codes have been drafted by experts, so they need to be applied by experts. (iii) Of course, in a number of instances, the draftsmen of the codifications managed to settle, with a stroke of their pen, deeply-rooted doctrinal disputes, and sometimes they reversed the legal position prevailing under the ius commune because they regarded it as unsatisfactory. Very widely, however, the codifications did not contain 'new' law, as far as the substance of

52 See also H. Kötz, ‘Taking Civil Codes Less Seriously’ (1987) 50 Modern Law Review 1 et seq (specifically addressing misconceptions prevailing in England).

53 Ch.-L. de Secondat Montesquieu, De l'Espit des Lois, 1748, Liv XXXIX, chap 16.

54 Mertens, n 15 above, 380 et seq. Some lawyers, among them Carl Gottlieb Svarez (the principal intellectual father of the Prussian code), argued that two codifications were necessary, one of them for judges and legal scholars, the other for the general population ('Volkskodex').

55 See Cartwright, Vogenauer and Whittaker, n 12 above; Zimmermann, n 49 above, 30 et seq; H. Koziol, 'Gedanken zur österreichischen Schadenersatzreform', in Bundesministerium der Justiz (ed), 200 Jahre ABGB (2012) 307 et seq. 
the rules contained in them is concerned. They rather bore certain characteristics of a restatement, for they were supposed to incorporate, and consolidate, 'the legal achievements of centuries'. ${ }^{56}$ As a result, they were heavily impregnated by Roman law. ${ }^{57}$ (iv) The codifications neither (as was sometimes feared) ${ }^{58}$ ossified the law, nor did they constitute a 'prison cell'59 for legal scholarship. They were the products of a legal tradition largely shaped by courts and legal scholarship, and they thus provided a statutory framework for the further development of the law by courts and legal writers. ${ }^{60}$ Often those courts and legal writers perpetuated old thinking patterns, thus establishing lines of continuity linking the old law to the new. ${ }^{61}$ With prudent, and characteristic, modesty Bernhard Windscheid, therefore, quite rightly described a code as 'no more than a moment in the development, ... merely a ripple in the stream'. ${ }^{62}(\mathrm{v})$ It is occasionally thought that the codifications of the $19^{\text {th }}$ and $20^{\text {th }}$ centuries are manifestations of a specifically national legal culture of the country within which they apply; and that they therefore need to be preserved as part of Europe's rich tradition of cultural diversity (rather than be sacrificed on the altar of legal unification). ${ }^{63}$ But this is correct only to a limited extent. It is true that the civil codes prevailing today differ

56 Windscheid, n 47 above, 75. Cf also Behrend, n 13 above, 230; Mertens, n 15 above, 33 et seq, 51 et seq; Cabrillac, n 5 above, 93 et seq; Jansen, $\mathrm{n} 7$ above, 17.

57 For the Code civil, see J. Gordley, 'Myths of the French Civil Code' (1994) 42 American Journal of Comparative Law 459 et seq; for the ABGB, see G.E. Kodek, '200 Jahre Allgemeines Bürgerliches Gesetzbuch - das ABGB im Wandel der Zeit' (2011) Österreichische Juristenzeitung 491 et seq; for the BGB, see R. Zimmermann, 'Römisches Recht und europäische Rechtskultur' (2007) Juristenzeitung 3 et seq.

58 See Cabrillac, $\mathrm{n} 5$ above, 96 et seq ('l'effet de cristallisation').

59 H. Wüstendörfer, 'Die deutsche Rechtswissenschaft am Wendepunkt' (1913) 110 Archiv für die civilistische Praxis 224.

60 Thus, the BGB was regarded by its draftsmen as 'an organic fabric of coherent rules. The seeds for its development are inherent in the principles on which they are based': Motive, in B. Mugdan, Die gesammten Materialien zum Bürgerlichen Gesetzbuch für das Deutsche Reich, volume I (Berlin: von Decker, 1899) 365. For France, see the famous, and often quoted statement by Portalis about the 'principes féconds en conséquences' which it is the task of legislation to determine: Zweigert and Kötz, n 50 above, 90. In France and Austria, it took some time before this was realized by legal scholarship; see Vogenauer, $n 23$ above, 650; Zweigert and Kötz, n 50 above, 96 et seq, 161 et seq. In Germany, Savigny's Historical School had established a strong and fertile tradition of doctrinal legal scholarship (which also significantly influenced France, Austria and many other jurisdictions from the second half of the 19th century onwards).

61 See Zimmermann, n 49 above, 17 et seq.

62 Windscheid, $\mathrm{n} 47$ above, 75 et seq.

63 On the issue of cultural diversity, and the relationship between code and culture, see Collins, $\mathrm{n} 28$ above, 124 et seq. 
in a number of respects, both as far as their content and 'style'64 are concerned. But the awareness and appreciation of these characteristics in comparative perspective does not tend to be wide-spread among the general population, and often not even among lawyers; and their contribution towards a sense of national identity tends to be limited, at best. Resistance against legal unification on a European level is due, very largely, to the conservative impulse not to see a legal instrument that has been well-tried and that is enveloped by thick and reasonably reliable layers of case law and legal doctrine replaced by something unfamiliar; and, of course, to well-founded scepticism about the quality of European legislation. Also, the differences originating in the fragmentation of the civilian tradition appear to be, much more often than not, historically contingent rather than determined by cultural conditions. They are indeed, 'diversités accidentelles entre législations régissant des peuples de même civilisation' ${ }^{65}$ This is, perhaps, most obvious for contract law (ie the field of law that usually tops any legal harmonization agenda), ${ }^{66}$ but it is true much more widely, eg also in the law of succession. Specific legal rules and institutions tend to be transferred, mentally, to the shrine of national cultural heritage once they have been received, and used for some time, no matter whether they originated in another nation's law. ${ }^{67}$ The history of the holograph will can, for example, be told along these lines. ${ }^{68}$ Finally, the Code civil could hardly have served as a model for the codes of so many other countries if it had been wedded to a specifically French legal culture. And indeed, quite in line with their rationalist origins, neither the Code civil nor the ABGB had been conceived by its draftsmen as specifically French or Austrian. ${ }^{69}$ (vi) None the less, once the codifications had entered into force, they came to be regarded as

64 Zweigert and Kötz, n 50 above, 63 et seq.

65 E. Lambert, Congrès international de droit comparé, Procès-verbaux des séances et documents, volume I (1905) 38; cf also Jansen, n 7 above, 63.

66 Cf O. Lando, 'Optional or Mandatory Europeanisation of Contract Law' (2000) 8 European Review of Private Law 61: 'Contract Law is not folklore'.

67 For a similar argument, see Michaels, n 87 below, 153.

68 R. Zimmermann, ‘Testamentsformen: “Willkür” oder Ausdruck einer Rechtskultur?’ (2012) 76 Rabels Zeitschrift für ausländisches und internationales Privatrecht 471; this is based upon the research carried out in K. Reid, M.J. de Waal and R. Zimmermann (eds), Testamentary Formalities (Oxford: Oxford University Press, 2011). Cf also, as far as the law relating to undeserving beneficiaries is concerned, R. Zimmermann, 'Erbunwürdigkeit: Die Entwicklung eines Rechtsinstituts im Spiegel europäischer Kodifikationen', in P. Apathy et al. (ed), Festschrift für Helmut Koziol (Vienna: Sramek, 2010) 463 et seq.

69 W. Brauneder, 'Vernünftiges Recht als überregionales Recht: Die Rechtsvereinheitlichung der österreichischen Zivilrechtskodifikationen 1786-1797-1811', in R. Schulze (ed), Europäische Rechts- und Verfassungsgeschichte (Berlin: Duncker \& Humblot, 1991) 137. 
comprehensive and closed systems of legal rules, ${ }^{70}$ constituting autonomous interpretational spaces. ${ }^{71}$ After all, they were a piece of legislation, enacted by the legislature of a specific state and applicable only within the limited territory for which that legislature was competent to lay down the law. At the same time, the codifications moved to the centre stage in legal training and legal literature and became autonomous subjects of research and teaching, ${ }^{72}$ giving rise to an inwardlooking scholarship of an almost exclusively exegetical nature. This was to lead, eventually, to the horizontal isolation of the national legal doctrines developing around the national legal codifications, and thus to the national fragmentation also on the level of legal scholarship, that was characteristic for large parts of the $20^{\text {th }}$ century. That, in turn, stimulated the rise of comparative law. ${ }^{73}$ However, comparative law was seen to constitute a legal sub-discipline in its own right, entirely independent of the various national legal doctrines, and it consisted of, essentially, a comparison of legal systems. ${ }^{74}$ Equally, codification marked the beginning of a great age of discovery for Roman law and legal history, for legal historians could now, unaffected by any consideration of how historical sources might be applied in contemporary legal practice, devote their attention to understanding those historical sources in the context of their bygone age. ${ }^{75}$ The downside of this was a vertical isolation of the national legal doctrines: ${ }^{76}$ in spite of all the continuities mentioned earlier - they were increasingly lost sight of and faded from the general consciousness ${ }^{77}$ - legal scholarship was no longer conceived of as a 'historical science'. (vii) But is a 'historical legal science' still possible today?

70 See H. Hübner, Kodifikation und Entscheidungsfreiheit des Richters in der Geschichte des Privatrechts (Hanstein: Königstein, 1980) 67.

71 Cf also Cabrillac, n 5 above, 105 ('... comme un univers autonome qui se suffit à lui-même').

72 This was different with regard to the Prussian code throughout the $19^{\text {th }}$ century, and to the Austrian code for the second half of the century as a result of the reforms inspired by Leo Graf Thun-Hohenstein and Joseph Unger when Roman law, in its contemporary, pandectist version, was attributed the status of a general theory of private law; see, for Prussia, P. Hellwege, 'Allgemeines Landrecht für die Preußischen Staaten', in MaxEuP, n 4 above, 58 et seq; for Austria, W. Doralt, 'Allgemeines Bürgerliches Gesetzbuch', in MaxEuP, n 4 above, 48.

73 See the contributions in Part I of M. Reimann and R. Zimmermann (eds), The Oxford Handbook of Comparative Law (Oxford: Oxford University Press, 2008); R. Michaels, 'Rechtsvergleichung', in MaxEuP, n 4 above, 297 et seq.

74 J. Gordley, 'Comparative Law and Legal History', in Reimann and Zimmermann, n 73 above, 761.

75 Zimmermann, $\mathrm{n} 45$ above, 22 et seq.

76 Cf also Cabrillac, $n 5$ above, 90 et seq ('l'effet de rupture').

77 The paradox is also noted by Cabrillac, $\mathrm{n} 5$ above, 93 et seq, who refers to '[une] perte de mémoire' and to Portalis who stated: 'Si l'on peut dire qu'il n'y a rien de nouveau parce que le présent tient toujours plus ou moins au passé, on pourra dire aussi qu'il n'y a rien d'ancien, 
Not if one regards contemporary law as 'something new, created by the need of the present day and the sovereign will of the modern legislature'. ${ }^{78}$ Applying the law would then be fundamentally different from the pre-codification era when 'a legal source expressly anchored in history' ${ }^{79}$ was at the centre of the ius commune. However, even apart from the fact that a codification is 'but a moment in the development', ${ }^{80}$ that moment also lies in the past. Two of the 'modern' codifications are now more than two centuries old, others more than one century. They are still sources of law but they are also historical documents, created at a specific time and reflecting specific conditions and intellectual influences. They can, therefore, only properly be understood by way of historical analysis, taking account not only of the travaux préparatoires but also of the legal position prevailing before their enactment, no matter whether they were intended to perpetuate that position or to change it. Moreover, they have become the basis for doctrinal developments, spanning considerable periods of time, that have to be understood and assessed in historical perspective as well. These are the reasons why it has been thought necessary to publish a historical commentary to the BGB. ${ }^{81}$ Similar endeavours concerning the other codes would be most welcome. (viii) No modern codification satisfies the ideal of 'completeness' ${ }^{82}$ Of course, there are the layers of case law and legal doctrine which anybody who wishes to apply the law has to be thoroughly familiar with. But there are also a number of areas of the law the development of which has taken place largely outside of the framework of the codifications. ${ }^{83}$ The most prominent modern example is consu-

parce que les institutions ou les coutumes les plus anciennes sont dès leur origine constamment et plus ou moins modifiées par les institutions ou par les mœurs présentes'.

78 K. Cosack, in H. Planitz (ed), Die Rechtswissenschaft der Gegenwart in Selbstdarstellungen, volume I (Leipzig: Meiner, 1924) 16.

79 Caroni, $\mathrm{n} 3$ above, 39.

80 Supran 62.

81 M. Schmoeckel, J. Rückert and R. Zimmermann (eds), Historisch-kritischer Kommentar zum $B G B$, volume I (Tübingen: Mohr Siebeck, 2003); volume II (Tübingen: Mohr Siebeck, 2007); volume III (due to appear in 2013). For the programme of that endeavour, see the foreword of the editors as well as 31 et seq. See further S. Meier, 'Historisch-kritisches Kommentieren am Beispiel des HKK' (2011) 19 Zeitschrift für Europäisches Privatrecht 537 et seq; M. Vec, 'Flagschiffe und Stiefkinder: Rechtsgeschichte als historische Kommentierung des geltenden Rechts' (2011) 19 Zeitschrift für Europäisches Privatrecht 547 et seq; cf also, in this context, F. Ranieri, 'Europäische Rechtsgeschichte zwischen Rechtsvergleichung und Rechtsdogmatik, zugleich eine Reflexion über den Weg zu einem Europäischen Zivilrecht' (2011) 19 Zeitschrift für Europäisches Privatrecht 564 et seq.

82 Supran 22.

83 For France, see Cabrillac, n 5 above, 74 et seq; for Germany, see R. Stürner, 'Der hundertste Geburtstag des BGB - eine nationale Kodifikation im Greisenalter?’ (1996) Juristenzeitung 742. 
mer contract law. In Germany, this tradition of excluding from the general private law codification matters which were considered to be of a special nature dates back to the $19^{\text {th }}$ century, and neither the statute concerning instalment sales (1894) nor the one imposing strict liability for personal injuries sustained in the operation of a railway (1871) was, therefore, included in the code. ${ }^{84}$ The apparently uninhibited growth of ever new specialized sub-disciplines, and the flood of legislation dealing with specific issues, have led some authors in the second half of the $20^{\text {th }}$ century to refer to a crisis of the idea of codification, ${ }^{85}$ or even to an age of decodification. ${ }^{86}$ Others have attempted to explain the situation by referring to two rationalities: the 'juridical' private law that has always existed as either common law or codification, and the 'instrumentalist' private law that has almost always taken the form of specific statutes. ${ }^{87}$ But it is anything but easy to disentangle these rationalities. Is the protection of a typically disadvantaged party an extra-legal end which is pursued by 'instrumentalist' private law? That might explain the statutes on consumer protection. But what about the rules on 'usury' or undue influence which form part of the general private law? Or what about the rules on product liability and unfair standard terms of business? In spite of having been laid down (or still being laid down) in specific statutes, they reflect concerns and policies pursued more broadly within the general civil codes. The perception of two different rationalities also appears to inspire the call for the drafting of a separate code of consumer contract law. ${ }^{88}$ But wherever such codes have been enacted on the national level they have turned out to be mere compilations. ${ }^{89}$ They constitute neither a comprehensive nor a systematic set of rules. The

84 For details, see R. Zimmermann, 'Consumer Contract Law and General Contract Law', in: R. Zimmermann, n 49 above, 163 et seq; Mertens, n 15 above, 348.

85 Wieacker, n 1 above; cf also, eg Meder, n 31 above, 483.

86 N. Irti, L'età della decodificazione ( $4^{\text {th }}$ ed, Milan: Giuffrè, 1999); cf also F. Kübler, 'Kodifikation und Demokratie' (1969) Juristenzeitung 645 et seq; Caroni, n 3 above, 87 et seq; Cabrillac, n 5 above, 114 et seq; Schmidt (2009), n 4 above, 146 et seq. But see H. Kötz, 'Schuldrechtsüberarbeitung und Kodifikationsprinzip', in A. Dieckmann et al. (ed), Festschrift für Wolfram Müller-Freienfels (Zurich: Schulthess, 1986) 395 et seq; Zimmermann, n 4 above, 105 et seq.

87 R. Michaels, 'Of Islands and the Ocean: The Two Rationalities of European Private Law', in R. Brownsword, H.W. Micklitz, L. Niglia and S. Weatherill (eds), The Foundations of European Private Law (Oxford: Hart, 2011) 139 et seq.

88 See, eg, C. Wendehorst, '1811 and all that - das ABGB im Prozess europäischer Rechtsentwicklung', in Vienna Law Inauguration Lectures, volume 2 (Vienna: Manz, 2010) 36 et seq.

89 This applies to the Code de la Consommation in France as much as to the Codice del Consumo in Italy and the Konsumentenschutzgesetz in Austria; see H. Rösler, 'Consumer and Consumer Protection Law', in MaxEuP, n 4 above, 372. 
most ambitious attempt to present the existing European consumer contract law 'in a systematic and coherent fashion', the so-called Acquis Principles, ${ }^{90}$ has demonstrated that the acquis communautaire cannot possibly be understood without reference to the traditional European private law, as we find it in the existing national legal systems (acquis commun). ${ }^{91}$ An assessment of the Acquis Principles should thus have put an end to the oil-and-water approach that wants to perpetuate the separation between two distinctive bodies of law. What is required is a renewed effort to integrate consumer contract law into a general code of contract law: for after having been properly revised in terms of intellectual coherence as well as consistency of concepts, policies and values, ${ }^{92}$ it could easily be subjected to a juridical rationality under the auspices of a material notion of freedom of contract. The rules on consumer protection can thus be seen as legitimate attempts to sustain private autonomy by providing mechanisms which aim at preventing contracts from coming into existence, or from being enforced, which cannot be regarded as the result of acts of self-determination of both parties concerned. All the mechanisms used in this context are perfectly familiar to general private law. ${ }^{93}$

\section{6}

Four of the five oldest private law codifications still in existence today have recently celebrated their $200^{\text {th }}$ and $100^{\text {th }}$ anniversaries respectively: the Code civil

90 Research Group on the Existing EC Private Law (Acquis Group), Principles of the Existing EC Contract Law (Acquis Principles), Contract II (Munich: Sellier, 2009) xxiii.

$91 \mathrm{~N}$. Jansen and R. Zimmermann, 'Restating the Acquis Communautaire? A Critical Examination of the "Principles of the Existing EC Contract Law"' (2008) 71 Modern Law Review 516 et seq.

92 For a proposal, see H. Eidenmüller, F. Faust, H.C. Grigoleit, N. Jansen, G. Wagner and R. Zimmermann, Revision des Verbraucher-acquis (Tübingen: Mohr Siebeck, 2011); for a summary in English, see H. Eidenmüller, F. Faust, H.C. Grigoleit, N. Jansen, G. Wagner and R. Zimmermann, 'Towards a Revision of the Consumer Acquis' (2011) 48 Common Market Law Review 1077 et seq; cf also, eg, S. Augenhofer, 'Die Zukunft des Europäischen Verbraucherrechts und seine Bedeutung für die Weiterentwicklung des Vertrags- und Wettbewerbsrechts', in S. Grundmann (ed), Festschrift 200 Jahre Juristische Fakultät der Humboldt-Universität zu Berlin (Berlin: de Gruyter, 2010) 1062 et seq.

93 For a detailed discussion along these lines, see C. Canaris, 'Wandlungen des Schuldvertragsrechts - Tendenzen zu seiner "Materialisierung"' (2000) 200 Archiv für die civilistische Praxis 274 et seq; Zimmermann, $\mathrm{n} 84$ above, 205 et seq (for further references cf, in particular, n 461). 
in $2004^{94}$ and the ABGB in $2011^{95}$ with considerable aplomb, the Swiss ZGB $(2007)^{96}$ and OR (2011) ${ }^{97}$ and the German BGB (2000) ${ }^{98}$ in a more low key manner. It was widely agreed that by and large, and in spite of the desirability of certain reforms, the national codifications have stood the test of time and have served their respective national communities well. They have turned out to be suffi-

94 Cf Le Code civil 1804-2004: Livre du Bicentenaire (Paris: Dalloz, 2004); Université Pantéon-Assas (Paris II) (ed), 1804-2004, Le Code civil: Un passé, un présent, un avenir (Paris: Dalloz, 2004); D. Heirbaut and G. Martyn (eds), Napoleons nalatenschap: Tweehonderd jaar Burgerlijk Wetboek in België (Mechelen: Kluwer, 2005); J. Dunand and B. Winiger (eds), Le Code civil Français dans le droit européen (Bruxelles: Brulant, 2005); A. Wijffels (ed), Le Code civil entre ius commune et droit privé européen (Bruxelles: Brulant, 2005); W. Schubert and M. Schmoeckel (eds), 200 Jahre Code civil: Die napoleonische Kodifikation in Deutschland und Europa (Köln: Böhlau, 2005); cf also the overview by L. Pfister, 'Zweihundertjähriges Jubiläum des Code civil' (2011) 33 Zeitschrift für Neuere Rechtsgeschichte 241 et seq.

95 Österreichischer Juristentag (ed), Festveranstaltung Österreichischer Juristentag und Bundesministerium für Justiz 200 Jahre ABGB vom 10. November 2011 (Vienna: Manz, 2012); C. Fischer-Czermak, G. Hopf, G. Kathrein and M. Schauer (eds), Festschrift 200 Jahre ABGB (Vienna: Manz, 2011); E. Berger (ed), Österreichs Allgemeines Bürgerliches Gesetzbuch (ABGB): Eine europäische Privatrechtskodifikation, volume III (Berlin: Duncker \& Humblot, 2010); C. Fischer-Czermak, G. Hopf, G. Kathrein and M. Schauer (eds), ABGB 2011: Chancen und Möglichkeiten einer Zivilrechtsreform (Vienna: Manz, 2008); B. Dölemeyer and H. Mohnhaupt (eds), 200 Jahre ABGB: Die österreichische Kodifikation im internationalen Kontext (Frankfurt: Klostermann, 2012); Kodek, n 57 above, 490 et seq; R. Welser, 'Verdienste und Stärken des ABGB' (2012) Juristische Blätter 205 et seq; A. Thier, '200 Jahre Allgemeines Bürgerliches Gesetzbuch' (2011) 19 Zeitschrift für Europäisches Privatrecht 805 et seq.

96 'Hundert Jahre schweizerisches Zivilgesetzbuch' (2008) 72 Rabels Zeitschrift für ausländisches und internationales Privatrecht 661 et seq; '100 Jahre ZGB' (2007) 126 II Zeitschrift für Schweizerisches Recht; '100 Jahre ZGB - Der Mut zur Lücke' (2008) 26 recht 41 et seq; P. Breitschmid and T. Ansay (ed), 100 Jahre Schweizerisches ZGB, 80 Jahre Türkisches ZGB (Berlin: Berliner Wissenschafts-Verlag, 2008); J. Dunand (ed), Le centenaire du code civil suisse (Paris: Société de Législation Comparée, 2008); Association Franco-Suisse de Paris II, Le centenaire du Code civil suisse (Paris: Société de Législation Comparée, 2008).

97 H. Honsell, '100 Jahre Schweizerisches Obligationenrecht' (2011) 130 Zeitschrift für Schweizerisches Recht 5 et seq; P. Pichonnaz, 'Le Centenaire du Code des obligations' (2011) 130 Zeitschrift für Schweizerisches Recht 117 et seq; previously, see H. Peter, E.W. Stark and P. Tercier (eds), Hundert Jahre Schweizerisches Obligationenrecht (Fribourg: Universitätsverlag, 1982) (ie celebrating the centenary of the original version of the OR).

98 See the references in Zimmermann, $\mathrm{n} 49$ above, 28. Characteristic, as far as the BGB is concerned, also the passage by Haferkamp, n 49 above, 123, entitled 'an unloved codification'. This may be contrasted with what Cabrillac, $\mathrm{n} 5$ above, 102 et seq, writes about the 'passions amoureuses' evoked by the Code civil. 
ciently adaptable to constitute a satisfactory basis for the contemporary administration of justice in the field of private law. ${ }^{99}$

The national private laws of the member states of the European Union have, however, for the past thirty years, increasingly been subjected to the legislative activities of the European Union. European private law has emerged as a distinctive discipline. ${ }^{100}$ But the approach adopted by the European legislature has been fragmentary and incoherent. That has been criticized again and again. ${ }^{101}$ The question of a codification was thus bound to arise also on a European level. The first protagonist for this idea was the European Parliament when it issued, in 1989, a resolution 'on action to bring into line the private law of the Member States' ${ }^{102}$ It is, however, generally agreed that the European Union does not have the competence to introduce a comprehensive civil code along the lines of the national codifications. Under Article 114 TFEU measures for the approximation of the national laws may be adopted, as far as they have as their object the establishment and the functioning of the internal market. Such measures, arguably, include a codification of contract law. ${ }^{103}$ It is not surprising, therefore, that this is the field on which the European Commission has focused its attention. A

99 This also comes across in the relevant entries in MaxEuP, $\mathrm{n} 4$ above; cf G. Rehm, 'Code civil', in MaxEuP, n 4 above, 200 et seq; Doralt, n 72 above, 45 et seq; Haferkamp, n 49 above, 120 et seq; K. Siehr, 'Swiss Civil Code', in MaxEuP, n 4 above, 1644 et seq; K. Siehr, 'Swiss Code of Obligations', in MaxEuP, n 4 above, 1646 et seq.

100 N. Jansen, 'European Private Law', in MaxEuP, n 4 above, 637 et seq; R. Zimmermann, 'Comparative Law and the Europeanization of Private Law', in Reimann and Zimmermann, n 73 above, 539 et seq. - This paper, in line with its historical character, focuses on codifications in the field of private law (and, under 7, on the question of a European Civil code). For an insightful analysis of codification as a proposition for private international law on a European level, see A.M.E. Firrini, 'Qu’y a-t-il en un nom?: Un vrai code pour le droit international privé européen', in M. Fallon, P. Lagarde and S. Poillot-Peruzzetto (eds), Quelle architecture pour un code européen de droit international privé? (Bruxelles: Lang, 2011) 27 et seq.

101 Inter alia by the European Commission itself: 'Communication from the Commission to the European Parliament and Council, A More Coherent European Contract Law: An Action Plan', $\operatorname{COM}(2003) 68$ final. For comprehensive criticism of the acquis communautaire in private law, see also Collins, $\mathrm{n} 28$ above, 28 et seq.

102 'Resolution of the European Parliament of May 26, 1989 on action to bring into line the private laws of the Member States' OJEC 1989 C 158/400; cf also the contributions to

A. Hartkamp, M. Hesselink, E. Hondius, C. Mak and E. du Perron (eds), Towards a European Civil Code ( $4^{\text {th }}$ ed, Alphen aan den Rijn: Wolters Kluwer, 2011); M. Schmidt-Kessel, 'European Civil Code', in MaxEuP, $\mathrm{n} 4$ above, 553 et seq; Jansen and Rademacher, $\mathrm{n} 4$ above.

103 J. Basedow, 'A common contract law for the common market' (1996) 33 Common Market Law Review 1187. It does not, incidentally, include the enactment of the optional instrument in the field of contract law that is presently contemplated by the European Commission; see Max Planck Institute for Comparative and International Private Law (MPI), 'Policy Options for 
sequence of Communications was issued, first floating the idea of a codification of European contract law and then rejecting it, vacillating between a revision of the consumer acquis and the preparation of a document encompassing general contract law, sales contracts and insurance contracts, and introducing the notions of a Common Frame of Reference, an Optional Instrument, and a 'toolbox' for future action in the field of European contract law. ${ }^{104}$ Ultimately, a twopronged approach was adopted. On the one hand, a Consumer Rights Directive was issued on 25 October 2011. ${ }^{105}$ It does not, of course, constitute a European consumer code, nor even a comprehensive compilation, but a fairly unambitious consolidation of two of the previously existing directives. ${ }^{106}$ On the other hand, a Proposal for a Regulation on a Common European Sales Law was published on 11 October 2011. ${ }^{107}$ This is a much more significant step which has already unleashed a barrage of publications. ${ }^{108}$

Progress Towards a European Contract Law' (2011) 75 Rabels Zeitschrift für ausländisches und internationales Privatrecht 386 et seq.

104 See the contributions by S. Weatherill, M.J. Bonell, T. Wilhelmsson, B. Lurger and R. Zimmermann, in $4^{\text {th }}$ European Jurists' Forum, Proceedings (Vienna: Manz, 2008) 3 et seq, 85 et seq, 111 et seq, 175 et seq, 185 et seq.

105 Directive 2011/83/EU OJEC 2011 L 304/64. For comment, see C. Wendehorst, 'Die neue Richtlinie über die Rechte der Verbraucher', in B. Schenk et al. (ed), Festschrift für Irmgard Griss (Vienna: Sramek, 2011) 717 et seq; E. Hall, G. Howells and J. Watson, 'The Consumer Rights Directive: An Assessment of its Contribution to the Development of European Consumer Contract Law' (2012) 8 European Review of Contract Law 139 et seq; O. Unger, 'Die Richtlinie über die Rechte der Verbraucher - Eine systematische Einführung' (2012) 20 Zeitschrift für Europäisches Privatrecht 270 et seq.

106 For criticism and discussion of the previously intended, more comprehensive approach, based on the strategy of maximum harmonization, see B. Jud and C. Wendehorst (eds), Neuordnung des Verbraucherprivatrechts in Europa (Vienna: Manz, 2009); G. Howells and R. Schulze (eds), Modernising and Harmonising Consumer Contract Law (Munich: Sellier, 2009); B. Gsell, C. Herresthal (eds), Vollharmonisierung im Privatrecht (Tübingen: Mohr Siebeck, 2009); M. Stürner (ed), Vollharmonisierung im europäischen Verbraucherrecht? (Munich: Sellier, 2010).

$107 \operatorname{COM}(2011) 635$ final. The Common European Sales Law will be abbreviated CESL, the Draft submitted by the Commission DCESL. The DCESL has been published as Annex I to the Proposal for a Regulation on a Common European Sales Law (PR CESL).

108 R. Zimmermann, 'Perspektiven des künftigen österreichischen und europäischen Zivilrechts: Zum Verordnungsvorschlag über ein Gemeinsames Europäisches Kaufrecht' (2012) Juristische Blätter 2 et seq; H. Eidenmüller, N. Jansen, E. Kieninger, G. Wagner and R. Zimmermann, 'Der Vorschlag für eine Verordnung über ein Gemeinsames Europäisches Kaufrecht' (2012) Juristenzeitung 269 et seq; H. Schulte-Nölke, F. Zoll, N. Jansen and R. Schulze (eds), Der Entwurf für ein optionales europäisches Kaufrecht (Munich: Sellier, 2012); O. Remien, S. Herrler, P. Limmer (eds), Gemeinsames Europäisches Kaufrecht für die EU? (Munich:

C H Beck, 2012); M. Schmidt-Kessel, Ein einheitliches europäisches Kaufrecht? (Munich: Sellier, 
This is not the right place to provide a critical assessment of the proposed Regulation and of the DCESL appended to it, save perhaps to state that the latter is not a codification in the sense described above. ${ }^{109}$ For it is not intended to replace the previous law, ie the national legal rules on contract law, but to take its place next to them, as a second set of rules within the legal system of each of the EU's member states that may be chosen by the parties to a contract. ${ }^{110}$ Moreover, it is not comprehensive, for the Regulation itself mentions a number of matters to which the national law designated by the relevant rules on private international law remains applicable. These matters include illegality and immorality, representation, plurality of debtors and creditors, assignment, and setoff. ${ }^{111}$ None the less, the DCESL may be the nucleus of a European code of contract law properly so called, and perhaps even of a European Civil Code, ${ }^{112}$ and thus it may be appropriate to assess its chances of success against the background of the historical experiences gathered with respect to the idea of codification on a national level. We will first consider the arguments that have,

2012); C. Wendehorst and B. Zöchling-Jud, Am Vorabend eines Gemeinsamen Europäischen Kaufrechts (Vienna: Manz, 2012); B. Fauvarque-Cosson, 'Vers un droit commun européen de la vente' (2012) 188 Recueil Dalloz 34 et seq; the contributions in (2012) Revue des contrats 191 et seq; 'Trenta giuristi europei sull'idea di codice europeo dei contratti' (2012) 1 Contratto $e$ Impresa/Europa (numero speciale); and see the contributions by A. Stadler, S. Grundmann, B. Zöchling-Jud, D. Looschelders and S. Lorenz to the conference of the Zivilrechtslehrervereinigung that will be published in (2012) 212 Archiv für die civilistische Praxis.

109 Generally on the phenomenon of 'transjurisdictional codifications', see J. Basedow, 'Transjurisdictional Codification' (2009) 83 Tulane Law Review 974 et seq (pointing out that there is no such thing, so far, and stating, in particular, that the Convention on Contracts for the International Sale of Goods [CISG] is no codification in the sense outlined above). Cf also Jansen and Rademacher, $\mathrm{n} 4$ above, sub 2 ('None of [the standard features of a civil code] may be taken for granted in respect of a European Civil Code').

110 See Recital 10 to the PR CESL; for comment, see MPI, n 103 above, 400 et seq; M. Fornasier, “"28.” versus "2. Regime” - Kollisionsrechtliche Aspekte eines optionalen europäischen Vertragsrechts' (2012) 76 Rabels Zeitschrift für ausländisches und internationales Privatrecht 401 et seq; Eidenmüller, Jansen, Kieninger, Wagner and Zimmermann, n 108 above, 273 et seq; A. Stadler, 'Anwendungsvoraussetzungen und Anwendungsbereich des Common European Sales Law (CESL)' (2012) 212 Archiv für die civilistische Praxis 467 et seq.

111 Recital 27 to the PR CESL. But there are even more gaps; see Zimmermann, n 108 above, 9. On the problem of gap-filling, see MPI, n 103 above, 409 et seq.

112 This is the ambition of the draftsmen of the 'Draft Common Frame of Reference'; see N. Jansen and R. Zimmermann, “'A European Civil Code in All But Name”: Discussing the Nature and Purposes of the Draft Common Frame of Reference' (2010) 69 Cambridge Law Journal 98 et seq. 
in the past, been advanced in favour of codifications of private law ${ }^{113}$ and then look at other factors that have contributed to their success.

\section{7}

(i) A forceful argument in favour of codification has usually been the reduction of the complexity of legal sources. The European legal landscape today, however, looks neat and tidy when compared to that prevailing under the ius commune. There are, admittedly, close to thirty legal systems that may be applicable to a transnational legal dispute. But the conflict rules have, in important areas, been unified $^{114}$ and, as a result, the same substantive law will prevail wherever a dispute is litigated. Determination of the rules of a foreign legal system will not be easy, ${ }^{115}$ and a unification also of the substantive law will, therefore, entail practical advantages. But unlike under the ius commune it is not unclear which legal rules have to be applied. ${ }^{116}$ This also takes care of the closely related argument of legal certainty to be established, or at least advanced, by way of codification. ${ }^{117}$ The contrary may be true here, for the promulgation of a European codification would, for the foreseeable future and until the European Court of Justice has established Union-wide interpretative standards, have a distinctly unsettling effect. ${ }^{118}$ Also, legal proceedings would neither become fewer in number, nor be shortened. (ii) Some of the older codifications served what may be termed a 'constitutional' function: they were supposed to provide citizens with certainty about their rights and duties within, and vis-à-vis, the State. At the same time, they established the civil freedoms as well as many other essential principles

113 For a detailed analysis concerning the first wave of codifications, see P.A.J. van den Berg, The Politics of European Codification: A History of the Unification of Law in France, Prussia, the Austrian Monarchy and the Netherlands (Gronigen: Europa Law Publishers, 2007). This analysis provides the basis for the first four of the following points. Cf also Jansen and Rademacher, n 4 above, sub 1.

114 See the Rome I (contractual obligations), Rome II (non-contractual obligations), Rome III (divorce and legal separation) Regulations and the Proposal for a Regulation concerning the law of succession: R. Schulze and R. Zimmermann (eds), Europäisches Privatrecht: Basistexte $4^{\text {th }}$ ed, Baden-Baden: Nomos, 2012) I.90-I.105.

$115 \mathrm{Cf}$, eg, O. Lando, 'Principles of European Contract Law and UNIDROIT Principles: Moving from Harmonisation to Unification?' (2003) 8 Uniform Law Review 124 et seq.

$116 \mathrm{Cf}$ also Jansen, $\mathrm{n} 7$ above, 66 .

117 Cabrillac, $\mathrm{n} 5$ above, 68 et seq, 136 et seq.

118 Eidenmüller, Jansen, Kieninger, Wagner and Zimmermann, n 108 above, 286; J. Cartwright, ““Choice is good." Really?' (2011) 7 European Review of Contract Law 347. 
characterizing our private laws until today: the freedom of contract and of testation, the recognition of private property, equality before the law, etc. This was done particularly emphatically in the Code civil, ${ }^{119}$ but was noticeable also to a greater or lesser extent in the other codes. Today, the national constitutions largely discharge this function; after all, they no longer merely deal with the organization of the state, as they did in the $19^{\text {th }}$ century, but usually contain a catalogue of basic rights. On a supranational level in Europe we have the European Convention on Human Rights as well as the Charter of Fundamental Rights that is referred to in Article 6(1) of the Treaty of the European Union; we therefore no longer need a civil code for this specific purpose. ${ }^{120}$ (iii) The enactment of private law codifications often either followed closely on the heels of the creation of a modern state and thus constituted an expression of its sovereignty and a symbol of its national unity, or was intended to contribute towards cultural homogeneity and a national consciousness. The European Union is not a nation state, nor even a state; it is an international organization sui generis. ${ }^{121} \mathrm{~A}$ codification of European private law can be seen as part of a process of state formation, just as a Union citizenship or symbols such as a hymn or a flag. ${ }^{122}$ This, in fact, is what many observers fear: a European code will have a highly symbolic significance and thus, in a way, substitute for the failure of the project of a Constitutional Treaty. ${ }^{123}$ Given the prevailing mood among the citizens and governments of the EU member states, any argument in favour of a codification of European law based on such practical-political consideration - historically the 'practicalpolitical' considerations were the most influential ones ${ }^{124}$ - is likely to be counter-

119 Van den Berg, $\mathrm{n} 113$ above, 28 et seq subsumes this under the heading of the 'politicaltheoretical' argument in favour of codification; cf also P. Malaurie, 'Les dix premières années de notre siècle et le droit civil' (2010) La Semaine Juridique 781; Cabrillac, n 5 above, 104;

Basedow, n 109 above, 985. - For a modern constitutionalist argument in favour of a civil code, see Collins, $\mathrm{n} 28$ above, 91 et seq.

120 At least not a civil code in the sense in which the term is normally - and also presently understood. A 'civil code' in the sense of an 'economic constitution' along the lines envisaged by Collins, $\mathrm{n} 28$ above, 91 et seq is quite a different matter and may, indeed, be a useful device to contribute towards 'an integrated transnational civil society out of which a common European identity could be constructed', 2.

121 N. Colneric, 'European Union', in MaxEuP, n 4 above, 641 et seq.

122 Van den Berg, $\mathrm{n} 113$ above, 277 who concludes his book with the following statement: 'Is the project of a European codification part of a process of state formation after all? This Study makes clear that this is at least a possibility', 278; cf also Jansen, $\mathrm{n} 7$ above, 14 .

123 N. Colneric, 'European Constitution', in MaxEuP, n 4 above, 572 et seq. - For the ideological link between the Constitutional Treaty and a European civil code (though one conceived as an 'Economic Constitution'), see Collins, $\mathrm{n} 28$ above, 15 et seq, 91 et seq. 124 Van den Berg, n 113 above, 23 et seq, 273. 
productive: statehood on the European level is not as fervently desired as it was in $19^{\text {th }}$ century Germany or Italy; nor does it arouse the kind of patriotism characteristic of revolutionary or post-revolutionary France. It should also be noted that a CESL will have to be published in the 23 official languages of the European Union, all of them possessing the same binding force. While this will give rise to considerable difficulties in the application of a uniform European codification, ${ }^{125}$ it is also a poignant reminder that - unlike with the national codifications $^{126}$ - language cannot, on a European level, serve the function of a cultural glue. There is no European vernacular. ${ }^{127}$ (iv) It has usually been argued that a codification of private law, and in particular contract law, will facilitate trade and thus be beneficial to the economy. This is, in fact, the main reason advanced by the European Commission in favour of a CESL: it is to improve the functioning of the internal market by facilitating cross-border trade. By subjecting contracts to a uniform legal regime, it should be possible for businesses to lower their transaction costs. ${ }^{128}$ This is a plausible argument, though it is not as strong as is often made out. ${ }^{129}$ Tax laws, language problems, licensing and registration requirements and, particularly, the difficulties involved in litigating cases and enforcing judgments in other jurisdictions are at least as significant as the transaction costs caused by differing contract laws. ${ }^{130}$ Also, a number of examples

$125 \mathrm{MPI}, \mathrm{n} 103$ above, 431 et seq.

126 The Swiss codification constitutes an exception in view of the four official languages recognized in Switzerland. The Austrian code also had to be translated into a number of different languages in order to take account of the different nationalities united under the Habsburg crown; see W. Brauneder, 'Gesetzgebungslehre und Kodifikationspraxis am Beispiel des ABGB', in Dölemeyer and Mohnhaupt, n 95 above, 38.

127 T. Weir, 'Die Sprachen des europäischen Rechts: Eine skeptische Betrachtung' (1995) 3 Zeitschrift für Europäisches Privatrecht 368 et seq. Cf also Collins, n 28 above, 142 et seq, urging to resist '[the] temptation to devise a European Civil Code in one language'. - The English that is in the process of informally acquiring the status of a modern lingua Franca will never have the same culturally homogenizing effect as, eg, French for France. On the use of English cf also, in the present context, the remarks in (2007) Neue Juristische Wochenschrift 3332 et seq.

128 'Explanatory Memorandum PR CESL' section 1; 'Communication from the Commission to the European Parliament, the Council, the European Economic and Social Committee and the Committee of the Regions: A Common European Sales Law to facilitate cross-border transactions in the single market', $\operatorname{COM}(2011) 636$ final, section 1. For critical comment, see Collins, $\mathrm{n} 28$ above, 63 et seq.

129 According to two 'eurobarometer' surveys, the differing legal regimes do not, in the opinion of a large majority of businesses, constitute significant obstacles to crossborder trade: eurobarometers 320 and 321 (both from 2011), as referred to by Eidenmüller, Jansen, Kieninger, Wagner and Zimmermann, n 108 above, 286.

130 Eidenmüller, Jansen, Kieninger, Wagner and Zimmermann, n 108 above, 286. 
can be given of countries where differing contract laws hardly appear to be perceived as a trade barrier; English and Scots law provide an instructive example. ${ }^{131}$ Finally, the DCESL seems to be intended mainly for electronic trading, ${ }^{132}$ where special goodwill practices and reputational mechanisms considerably reduce the practical relevance of the legal regime. ${ }^{133}$ (v) If we now turn our attention to other factors that have contributed to the success of the national codifications we must note, in the first place, that their preparation usually took a long time and/or was facilitated by the existence of a well-established and welldocumented legal doctrine. Pandectist legal doctrine, as expounded by Bernhard Windscheid and other writers, provided the basis for the BGB; none the less, it took 22 years to prepare the code. ${ }^{134}$ The history of the Austrian codification reaches back to 1753 and thus extends over 58 years; ${ }^{135}$ the process was decisively advanced by Freiherr von Martini, who could draw upon generations of learning on Roman law, more recently neatly dressed up in Natural law's clothing. ${ }^{136}$ Walther Munzinger's ${ }^{137}$ Swiss Code of Obligations was only 13 years in the making, but could be based upon Johann Caspar Bluntschli's ${ }^{138}$ Code of Private Law of Zurich as well as upon the so-called Dresden Draft for a law of obligations. The preparation of the Code civil took hardly more than ten years, but its true fathers were authors whose works date from much earlier, particularly Jean Domat and Robert-Joseph Pothier. ${ }^{139}$ The DCESL, by contrast, has been prepared in great

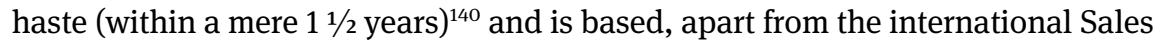
Convention, upon sets of model rules (Principles of European Contract Law,

131 T. Weir, 'Divergent Legal Systems in a Single Member State' (1998) 6 Zeitschrift für Europäisches Privatrecht 564 et seq.

132 See, eg, Recital 26 PR CESL.

133 W. Doralt, 'Rote Karte oder grünes Licht für den Blue Button? Zur Frage eines optionalen europäischen Vertragsrechts' (2011) 211 Archiv für die civilistische Praxis 24 et seq.

134 Overview in Haferkamp, n 49 above, 120 et seq; Zimmermann, n 49 above, 12 et seq.

135 Overview in Doralt, $\mathrm{n} 72$ above, 46.

136 Including, of course, the textbooks he had written himself. Martini was Professor of Natural Law, Institutions (of Roman Law) and Roman Legal History at the University of Vienna. For details, particularly also on his activities as a legal author, see M. Hebeis, Karl Anton von Martini (1726-1800): Leben und Werk (Frankfurt/M: Lang, 1996).

137 On Munzinger, see U. Fasel, 'Walther Munzinger - Vorbereiter der Schweizer Rechtseinheit' (2003) 11 Zeitschrift für Europäisches Privatrecht 345 et seq.

138 On Bluntschli, see T. Bühler, 'J.C. Bluntschli' (2009) 17 Zeitschrift für Europäisches Privatrecht 91 et seq.

139 See Rehm, n 99 above, 201 et seq; on the Ordonnances as percursors of French legal unity, see G. Rehm, 'Ordonnances', in MaxEuP, n 4 above, 1226 et seq.

140 The 'Expert Group' charged with the drafting of the DCESL was set up at the end of April 2010 (Commission Decision 2010/233/EU of 26 ${ }^{\text {th }}$ April 2010, OJEC 2010 L 105/109) and produced 
UNIDROIT Principles of International Commercial Contracts, Acquis Principles, Principles of European Law on Sales and Service Contracts, and Draft Common Frame of Reference $)^{141}$ that had been published only relatively recently and have not, so far, been subjected to rigorous scrutiny from an academic or practical point of view. (vi) The national codes were thus manifestations of a tradition of legal scholarship; with reference to the BGB, it has even been said that 'the code does not contain the source of law in itself but in the legal scholarship from which it was created'. ${ }^{142}$ As a consequence, the codifications were also designed in a way that left room for further scholarly development of the law. ${ }^{143}$ The DCESL, on the other hand, is hardly embedded in a similarly strong tradition of a genuinely European legal scholarship. Hein Kötz's pionieering book on European Contract Law only

a 'Feasibility Study for a future instrument in European Contract Law' at the beginning of May 2011; that Feasibility Study served as the basis for the DCESL, published in October 2011. 141 Part III of the Principles of European Contract Law (= PECL; eds O. Lando, E. Clive, A. Prüm and R. Zimmermann) was published in 2003, the second edition of the Acquis Principles ( 90 above) appeared in 2009 (first edition 2007), the Principles of European Law of the Study Group on a European Civil Code on Sales (= PEL S; eds E. Hondius, V. Heutger, C. Jeloschek, H. Sivesand and A. Wiewiorowska) in 2008 and on Service Contracts (eds M. Barendrecht, C. Jansen, M. Loos, A. Pinna, R. Cascão and S. van Gulijk) in 2007, the Draft Common Frame of Reference (eds C. von Bar and E. Clive) in 2008 (Interim Outline Edition) and 2009 (Full Edition), the new and extended version of the UNIDROIT Principles of International Commercial Contracts (ed UNIDROIT) in 2011 (the second extended version in 2004). For the details, see R. Zimmermann, 'The Present State of European Private Law' (2009) 57 American Journal of Comparative Law 479 et seq; R. Zimmermann, 'Europäisches Privatrecht - Irrungen, Wirrungen' in Bucerius Law School (ed), Begegnungen im Recht - Ringvorlesung zu Ehren von Karsten Schmidt (Tübingen: Mohr Siebeck, 2011) 322 et seq. - On the nature of these instruments as 'non-legislative codifications', see Jansen, $\mathrm{n} 7$ above, 59 et seq.

142 H.H. Jakobs, Wissenschaft und Gesetzgebung im bürgerlichen Recht nach der Rechtsquellenlehre des 19. Jahrhunderts (Paderborn: Schöningh, 1983) 160.

143 This had not always been the approach adopted by the draftsmen of the age of Enlightenment. The Prussian code is notorious for its 'passion for completeness and comprehensiveness' (Zweigert and Kötz, n 50 above, 137; Zweigert and Kötz also quote Wolfgang Kunkel's dictum that the Code was a 'monstrous anti-intellectual undertaking'; but this may be a modern exaggeration that does not do justice to the intentions of the code's draftsmen: see Mertens, $\mathrm{n} 15$ above, 287 et seq; Hellwege, $\mathrm{n} 72$ above, 58) and for its prohibition against taking account of legal doctrine so as not to 'corrupt' the law by means of 'independent' interpretation (on the tradition of such provisions, see H. Becker, 'Kommentierund Auslegungsverbot', in Erler [ed] [Handwörterbuch], n 4 above, 963 et seq). Similar sentiments prevailed, initially, in Austria, the distrust against judicial interpretation, let alone development, of the law also in France; see Hübner, n 70 above, 27 et seq; M. Miersch, Der sogenannte référé législatif (Baden: Nomos, 2000); Cabrillac, n 5 above, 107 et seq. For Italy, see A. Braun, 'Professors and Judges in Italy: It Takes Two to Tango' (2006) 26 Oxford Journal of Legal Studies 671 et seq. 
dates from 1996; ${ }^{144}$ and while much has been achieved since then, ${ }^{145}$ the national legal systems still constitute the primary objects of legal scholarship today. Contract law is probably the field with the most far-reaching pre-existing common ground, but even here there are issues with unresolved conceptual divergences, such as assignment, representation or plurality of debtors, ${ }^{146}$ which have been regarded as unfit for inclusion in the DCESL. The tensions between acquis communautaire and acquis commun continue to persist, ${ }^{147}$ and there have also been repeated shifts in the systematic design of European rules on contract law. ${ }^{148}$ In most other fields of private law a codificatory consolidation appears to be unimaginable, given the scarcity of scholarly groundwork. ${ }^{149}$ (vii) Apart from legal scholarship and the legislature, the courts have always been protagonists of legal development in Europe. The ius commune was a 'learned', ie scholarly, law but it was also a jurisprudentia forensis. ${ }^{150}$ Part of the success of the traditional codes is due to the fact that strong and centralized Supreme Courts were in place to ensure the uniform application, on the national level, of the uniform law. The French Cour de cassation dates back to the legislation of the French Revolution, ${ }^{151}$ the Austrian

144 H. Kötz, Europäisches Privatrecht, volume I (1996) (dealing, however, only with formation, validity, and content of contracts, as well as with contract and third parties); volume II (on nonperformance and remedies for non-performance, and to be written by another author) has not, to date, appeared.

145 For an overview, see Zimmermann, n 100 above, 548 et seq.

146 On representation, see D. Moser, Die Offenkundigkeit der Stellvertretung im deutschen und englischen Recht sowie in den internationalen Regelungsmodellen (Tübingen: Mohr Siebeck, 2010); J. Kleinschmidt, 'Representation', in MaxEuP, n 4 above, 1455 et seq; on assignment, see E. Kieninger, 'Das Abtretungsrecht des DCFR' (2010) 18 Zeitschrift für Europäisches Privatrecht 724 et seq, H. Kötz, 'Assignment', in MaxEuP, n 4 above, 75 et seq; on plurality of debtors, see S. Meier, 'Schuldnermehrheiten im europäischen Vertragsrecht' (2011) 211 Archiv für die civilistische Praxis 435 et seq; S. Meier, 'Solidary Obligations', in MaxEuP, $\mathrm{n} 4$ above, 1573 et seq. 147 Jansen and Zimmermann, n 91 above, 505 et seq.

148 Thus, the DCFR saw contract law as an integral part of a law of obligations; this decision has, in the meantime, been reversed (Feasibility Study and DCESL). The most surprising structural peculiarity of the DCESL consists in its part IV, entitled 'Obligations and remedies of the parties to a sales contract ...'; for details and criticism, see Eidenmüller, Jansen, Kieninger, Wagner and Zimmermann, n 108 above, 272; cf also M. Storme, (2011) 19 European Review of Private Law 343 ('... the main step backwards').

149 See N. Jansen, Binnenmarkt, Privatrecht und europäische Identität (Tübingen: Mohr Siebeck, 2004); Zimmermann (2009), n 141 above, 494 et seq.

150 H. Coing, Europäisches Privatrecht, volume I (Munich: C H Beck, 1985) 124 et seq; for further references, see R. Zimmermann, 'Roman-Dutch Jurisprudence and its Contribution to European Private Law' (1992) 66 Tulane Law Review 1712.

151 The Cour de cassation is special insofar as its task was originally to see to it that the courts did not deviate from the text of the Code civil; even interpreting a provision of the code 
Oberster Gerichtshof was the successor of Maria Theresia's Oberste Justizstelle, created in 1749 as part and parcel of the formation of the Austrian state, ${ }^{152}$ the modern Federal Court (Bundesgericht) for Switzerland was established in 1875, the German Reichsgericht in 1879. Within the European Union, of course, we have the European Court of Justice. It has to ensure that the law is observed in the interpretation and application of the European treaties and of the Union's secondary laws. It is no longer merely the Constitutional Court of the European Union, ${ }^{153}$ for, with the increase of secondary legislation, it has had to answer more and more questions in all kinds of legal fields, including contract law. But it would not, in its present structure, be able to cope with the flood of requests for preliminary rulings that would result from the enactment of a CESL. A fundamental reform of the European court structure would thus appear to be necessary for a comprehensive act of legislation in the field of private law to stand any chance of success. ${ }^{154}$ (viii) 'It is difficult to deny', writes Nils Jansen, ${ }^{155}$ 'that private law is in fact largely autonomous [vis-à-vis] political decision-making'. This is one of the reasons why codifications of private law have been written 'by commissions of scholars and other legal experts'. That is also true of the DCESL which has been prepared by an 'Expert Group' ${ }^{156}$ But that group has operated, from the outset, under unfortunate auspices. ${ }^{157}$ The selection of its members was subject to considerable criticism; ${ }^{158}$ it

was regarded as such deviation. But, in view of the fact that the text of the Code civil itself eventually recognized the need for, and legitimacy of, judicial interpretation, the Cour de cassation gradually took over the task of interpreting the code and of reversing judgements of the lower courts not because they had interpreted the code but because they had interpreted it wrongly: Zweigert and Kötz, n 50 above, 120.

152 E. Bruckmüller, 'Über die Lage der Habsburgermonarchie in den Jahrzehnten zwischen Maria Theresia und Metternich in Hinblick auf die Kodifikation des ABGB', in Dölemeyer and Mohnhaupt, $\mathrm{n} 95$ above, 11.

153 But see J. Pirrung, 'European Court of Justice', in MaxEuP, n 4 above, 583 et seq.

154 MPI, n 103 above, 434; J. Basedow, 'The Court of Justice and Private Law: Vacillations, General Principles and the Architecture of the European Judiciary' (2010) 18 European Review of Private Law 443 et seq.

155 Jansen, $\mathrm{n} 7$ above, 4.

156 For a list of its members, see 'Einsetzung einer Expertengruppe für einen gemeinsamen Referenzrahmen im Bereich des europäischen Vertragsrechts' (2010) 18 Zeitschrift für Europäisches Privatrecht 955.

157 For details, see Zimmermann (2011), n 141 above, 338 et seq. The insider's story is presented by H. Schulte-Nölke, 'Vor- und Entstehungsgeschichte des Vorschlags für ein Gemeinsames Europäisches Kaufrecht', in Schulte-Nölke, Zoll, Jansen and Schulze (eds), n 108 above, 1 et seq.

158 J. Basedow, H. Eidenmüller, C. Grigoleit, S. Grundmann, N. Jansen, E. Kieninger, H. Mansel, W.-H. Roth, G. Wagner and R. Zimmermann, 'Ein europäisches Privatrecht kommt - aber zu welchem Preis?' Frankfurter Allgemeine Zeitung of 1 July 2010, 8; K. Riesenhuber, 'A Competitive 
was given much too little time to accomplish its task and was, moreover, for a long time left in the dark about what task exactly it was supposed to accomplish; it was chaired by an official of the European Commission; and it was not really independent but had to follow, at crucial junctures, directions by the Commission. These factors will not enhance the inclination of the legal community (or rather: the various national legal communities) to accept the DCESL as a text emulating the existing national codifications in respectability.

\section{8}

All in all, therefore, the auspices for a European Code of Contract Law, let alone a Civil Code, are far from ideal. There is no common language in which it could be drafted. There is no Supreme Court in private law matters which could effectively ensure its uniform application. There is not yet a sufficiently strong European legal scholarship that could sustain it. Some arguments can be advanced in favour of a European code but they are fairly weak, and they lack any emotional appeal. In particular, there is not yet a strong feeling of European identity (comparable to the feeling of national identity in the $19^{\text {th }}$ century) that would give wings to such endeavour. And there is no sense of crisis that would make a codification appear indispensable.

At the same time the task to be accomplished is much more difficult than it was with any of the codifications in the past. It will have to encompass about thirty so far largely autonomous legal systems. Among them will be, for the first time, the English common law that is widely perceived to be very different from the continental tradition ${ }^{159}$ and that has, so far, been hostile to the idea of codification. ${ }^{160}$ Draftsmen of a European codification cannot resort to a well-established

\footnotetext{
Approach to EU Contract Law' (2011) 7 European Review of Contract Law 123 et seq; W. Doralt, 'Strukturelle Schwächen in der Europäisierung des Privatrechts' (2011) 75 Rabels Zeitschrift für ausländisches und internationales Privatrecht 270 et seq; S. Grundmann, 'Kosten und Nutzen eines Europäischen Optionalen Kaufrechts' (2012) 212 Archiv für die civilistische Praxis 530 et seq. 159 I do not share that perception; see, eg, R. Zimmermann, 'Der europäische Charakter des englischen Rechts: Historische Verbindungen zwischen civil law und common law' (1993) 1 Zeitschrift für Europäisches Privatrecht 4 et seq; R. Zimmermann, 'Roman Law and the Harmonization of Private Law in Europe', in Hartkamp, Hesselink, Hondius, Mak and du Perron (eds), $\mathrm{n} 102$ above, 42 et seq. But perceptions also matter!

160 For an attempt to correct misconceptions prevailing in England about codifications, see Kötz, $\mathrm{n} 52$ above, 1 et seq; cf also Cabrillac, $\mathrm{n} 5$ above, 45 et seq (codification not 'foncièrement incompatible' with the common law); Collins, n 28 above, 170 et seq. M. Bussani, on the other hand, calls on the civilian lawyers to rally around the project of a European Civil Code: 'A
} 
European legal doctrine but only to untested model rules of an academic nature. A codification of the law of torts/delict, unjustified enrichment, ${ }^{161}$ or property law appears to be inconceivable today. There is not enough common ground on a structural and conceptual level, and no agreement as to which of the various solutions found in the member states of the European Union is superior. The only fields in which a codification is at least imaginable are general contract law and the law of sales. But even here there are considerable difficulties. The acquis communautaire is in poor shape. There is no masterplan as to how to integrate the acquis communautaire with the acquis commun. As to the latter, a comparison of the various sets of model rules reveals that inspite of much common ground there are also many differences in detail. There has been no concerted effort to assess these differences in comparative perspective. ${ }^{162}$ Instead, one revision has followed the other with no explanation as to why certain choices have been made or certain changes have been implemented. It now appears to be widely acknowledged that the DCFR project was an overambitious aberration, ${ }^{163}$ and thus the wheel has been pulled round again. Whether, in view of the complex interactions between contract law, torts/delict, and unjustified enrichment, a codification confined to contract law is practicable, is another unresolved issue. ${ }^{164}$

The European Commission is now proposing what it regards as the least intrusive solution: the enactment of an optional instrument that will have to prove its mettle in legal practice. But even this proposal entails dangers, ${ }^{165}$ at least if the optional instrument is as full of gaps and difficulties of application, and as immature in its substance, as the DCESL is. ${ }^{166}$ And it raises the question whether

Streetcar Named Desire: The European Civil Code in the Global Legal Order' (2009) 83 Tulane Law Review 1083 et seq.

161 For the law relating to negotiorum gestio, see N. Jansen, 'Negotiorum Gestio and Benevolent Intervention in Another's Affairs: Principles of European Law?' (2007) 15 Zeitschrift für Europäisches Privatrecht 958 et seq.

162 For three specific areas, see N. Jansen and R. Zimmermann, 'Contract Formation and Mistake in European Contract Law: A Genetic Comparison of Transnational Model Rules' (2011) 31 Oxford Journal of Legal Studies 625 et seq; R. Zimmermann, 'Die Auslegung von Verträgen: Textstufen transnationaler Modellregelungen', in R. Richardi et al (eds), Festschrift für Eduard Picker (Tübingen: Mohr Siebeck, 2010) 1353 et seq.

163 See Zimmermann (2011), n 141 above, 336.

164 This was the consideration that led Christian von Bar to extend the DCFR-project beyond contract law; see C. von Bar, 'Die Mitteilung der Europäischen Kommission zum Europäischen Vertragsrecht' (2001) 9 Zeitschrift für Europäisches Privatrecht 799 et seq.

165 They are analyzed in Eidenmüller, Jansen, Kieninger, Wagner and Zimmermann, n 108 above, 285 et seq.

166 See the summary of a special meeting of private law professors from Germany, Austria and Switzerland in Bonn on 20/21 April 2012, (2012) 212 Archiv für die civilistische Praxis 471. 
European legal harmonization has to be brought about by way of legislation. Implicit in this is an inquiry as to whether private law can be conceived without, or beyond, the state. ${ }^{167}$ This is all the more pertinent in view of the fact that before the age of codification, for obvious reasons, private law and its validity were not connected with the idea of the sovereign state's control over the law. ${ }^{168}$ The ius commune was a kind of common law developed by courts and legal writers on the basis of a body of legal rules that had come to be usu receptum. It had an inherent flexibility and potential for adaptation and development. ${ }^{169}$ And since its validity was not confined by political borders, it was constitutive of, and sustained by, a European legal scholarship. The English common law, developed within a state that had been centralized at an early stage, has also not been 'enacted' by any ruler, but was developed predominantly by the courts (and also, from time to time and, since the $19^{\text {th }}$ century increasingly, by legal writers). In the United States we have the 'Restatements' which have rendered a significant contribution to the emergence of the notion of a national private law. ${ }^{170}$ The Restatements have inspired the work of the Lando Commission which resulted in the publication of the Principles of European Contract Law ${ }^{171}$ and they may also inspire the agenda of the European Law Institute ${ }^{172}$ (the creation of which has, in turn, been suggested by the success of the American Law Institute, a private institution that has been founded 'to promote the clarification and simplification of the law ... [and] to serve the better administration of justice'). ${ }^{173}$

These are just some of the alternatives to legislative unification of the law. A number of other strategies for strengthening convergence are imaginable, ${ }^{174}$

167 For a detailed investigation, see N. Jansen and R. Michaels (eds), Beyond the State: Rethinking Private Law (Tübingen: Mohr Siebeck, 2008); F. Cafaggi, 'Private Regulation in European Private Law', in Hartkamp, Hesselink, Hondius, Mak and du Perron (eds), n 102 above, 91 et seq.

168 'It is general historical knowledge that the connection between the law and the state is of rather recent origin': Jansen, $\mathrm{n} 7$ above, 13.

169 H.J. Berman, Law and Revolution: The Formation of the Western Legal Tradition (Cambridge, Massachusetts: Harvard University Press, 1983) 9.

170 R. Michaels, 'Restatements', in MaxEuP, n 4 above, 1464 et seq; Jansen, $\mathrm{n} 7$ above, 50 et seq.

171 Supra, n 140.

172 R. Zimmermann, 'Challenges for the European Law Institute' (2012) 16 Edinburgh Law Review 5 et seq.

173 J. Zekoll, 'Das American Law Institute - ein Vorbild für Europa?', in R. Zimmermann (ed), Nichtstaatliches Privatrecht: Geltung und Genese (Tübingen: Mohr Siebeck, 2008) 101 et seq.

174 See, eg, the contributions to the symposium 'Alternativen zur legislatorischen Rechtsvereinheitlichung' (1992) 56 Rabels Zeitschrift für ausländisches und internationales Privatrecht 215 et seq; Collins, n 28 above, 210 et seq. 
among them legal education. ${ }^{175}$ Ultimately everything depends on whether one wants to see a European legal culture grow before a reference text is cast in legislation, or whether one shares the belief that the growth of a European legal culture can be decisively advanced by an act of legislation. ${ }^{176}$ In this sense, it is the dispute between Savigny and Thibaut revived, after two hundred years, on a European level. ${ }^{177}$ We no longer believe in the exemplary character of a historical source of law as ratio scripta, and we have lost the confidence to figure out a 'law of reason'. Nor do we have much trust in the rationality of the political process, particularly at the European level. As legal scholars we rely on the strength of rational arguments exchanged in an open discourse. Codification is not, of course, a 'prison cell'178 but it has a tendency to limit the parameters of such discourse. At the present stage of the development, such limitation would appear to me to be distinctly unwelcome. ${ }^{179}$

175 A. Flessner, 'Rechtsvereinheitlichung durch Rechtswissenschaft und Juristenausbildung'

(1992) 56 Rabels Zeitschrift für ausländisches und internationales Privatrecht 243 et seq;

H. Kötz, 'Europäische Juristenausbildung' (1993) 1 Zeitschrift für Europäisches Privatrecht 268 et seq; F. Ranieri, Juristen für Europa (Münster: LIT-Verlag, 2006) (with comprehensive references); cf also A. Voßkuhle, 'Das Leitbild des “europäischen Juristen” - Gedanken zur Juristenausbildung und zur Rechtskultur in Deutschland' (2010) 1 Rechtswissenschaft 326 et seq.

176 The latter view is taken, eg, by 0. Lando, 'Culture and Contract Law' (2007) 3 European Review of Contract Law 17 et seq; Lando, n 115 above, 123 et seq; J. Basedow, 'A common contract law for the common market' (1996) 33 Common Market Law Review 1192 et seq; J. Basedow, 'Codification of Private Law in the European Union: The Making of a Hybrid' (2001) 9 European Review of Private Law 35 et seq. The idea of a code, on the model of the national codes, at the European level is rejected by, inter alia, J. Smits, 'The Draft Common Frame of Reference, Methodological Nationalism and the Way Forward' (2008) 4 European Review of Contract Law 270 et seq; S. Grundmann, 'On the Unity of Private Law from a Formal to a Substance-Based Concept of Private Law' (2010) 18 European Review of Private Law 1055 et seq; S. Grundmann, 'The Future of Contract Law' (2011) 7 European Review of Contract Law 509 et seq (codification is without alternatives for the development of a coherent supranational contract law, but 'the classical form of codes cannot be reconciled with the complexity of the modern, globalized world').

177 The parallel is also explicitly drawn by Lando, n 115 above, 127 et seq. - For lessons that can be learnt for the emergence of a European private law from the history of unification of regionally defined private laws in $19^{\text {th }}$ century Germany, see A.J. Kanning, 'The Emergence of a European Private Law: Lessons from 19 ${ }^{\text {th }}$ Century Germany' (2007) 27 Oxford Journal of Legal Studies 193 et seq.

178 Supra, n 59.

179 See also, along very similar lines, Doralt, n 158 above, 268 et seq; Grundmann, n 158 above, 502 et seq. 